Original Research Paper

\title{
A Blueprint for a Knowledge Bourse, a Financial Innovation for an Information Age
}

\author{
${ }^{1}$ Osama S. Tayyeb, ${ }^{2}$ Isam Yahia Al-Filali and ${ }^{3}$ Giulio M. Gallarotti \\ ${ }^{1,2}$ King Abdulaziz University, Jeddah, Saudi Arabia \\ ${ }^{3}$ Department of Government, Wesleyan University, Middletown, Connecticut, USA
}

\author{
Article history \\ Received: 24-05-2015 \\ Revised: 25-06-2015 \\ Accepted: 21-10-2015 \\ Corresponding Author: \\ Giulio M. Gallarotti \\ Department of Government, \\ Wesleyan University, \\ Middletown, Connecticut, \\ 06459-0019, B: (860) 685-2496 \\ H: (860) 345-3493, \\ Fax: (860) 685-2241, USA \\ Email: ggallarotti@wesleyan.edu
}

\begin{abstract}
The world economy is in the midst of the next stage of its evolution, one that operates robustly in the framework of an information age. The idea of a "knowledge or information society" has become a benchmark of economic policies and business practices in both developed and developing nations. Many nations have firmly set their sights on transitioning to knowledge economies, as reflected in the vast investments in information technologies and related economic aspects across countries. This article proposes a model for the development of a financial innovation that would vigorously promote such a transition: A Knowledge Bourse.
\end{abstract}

Keywords: Knowledge Bourse, Knowledge Economy, Information Economy, Financial Innovation

\section{Introduction}

The world economy is in the midst of the next stage of its evolution, one that operates robustly in the framework of an information age. The idea of a "knowledge or information society" has become a benchmark of economic policies and business practices in both developed and developing nations. Consequently many nations have firmly set their sights on transitioning to knowledge economies, as reflected in the vast investments in information technologies and related economic aspects. This article offers a model for the development of a financial innovation that would vigorously promote such a transition: A Knowledge Bourse. Section II describes a knowledge economy. Section III discusses how present financial instruments are limited in promoting a transition to a knowledge economy. Section IV presents a rationale for the creation of a Knowledge Bourse. Section V presents a detailed strategy through which a Knowledge Bourse can be created. Section VI offers brief concluding remarks (The blue print for a Knowledge Bourse presented here is applicable to any economic system and culture. But since much of the previous work of the authors has been in conceptualized within the context of finance within an Islamic culture, they have also added some indicators on how this Bourse could be operationalized in a way that is consistent with Sharia law).

\section{What is a Knowledge Economy?}

The idea of a knowledge economy goes back at least to the 1960s and the work of Peter Drucker. Drucker first introduced the concepts of knowledge workers and knowledge organizations in The Effective Executive (1966). Such workers and organizations produced "knowledge, ideas and information." This identification of knowledge as a specific factor of production introduced a new input into the theory of the firm, which until this time emphasized the value of only tangible inputs such as physical labor and non-human capital. Drucker went on to underscore and generate greater interest in the subject of the knowledge economy in The Age of Discontinuity (Drucker 1969), where he devoted an entire chapter to the subject. His ideas would go on to create an impressive legacy as the knowledge economy became a fixture in the pantheon of economic science's central issues. The knowledge economy (also called the information economy, knowledge-based economy and knowledge society) represents what some consider the fourth stage in the history of economic development: From the agrarian or pre-industrial age (pre-19th century-agricultural sector), to the industrial age (19th to mid 20th century-manufacturing), to the post-industrial (mid-20th century-present-service sector) and finally to the information age (late 20th-21st century-knowledge, information technology, innovation and human capital). In reality, our present age is an amalgam of all four ages, as the global economy features all four basic models of economic relations. The knowledge economy in the fourth stage has an especially strong potential for interaction effects with production models of the first three stages in that its components can have a pronounced impact on the 
state of the other modes of economic organization. Hence the knowledge age may be a culmination in economic evolution in that it has introduced the principal means of guiding and coordinating all other forms of economic activity. As outputs, knowledge and information technologies have created entirely new markets. The products themselves serve multifaceted and pervasive uses in modern society. As inputs they are the foundation for improved management, product and scientific innovations, increased efficiency in the production of goods and services and economic growth (Powell and Snellman 2004).

There is much debate on the issue of the knowledge economy, from its nature (is knowledge most important as an input or as an output?) to its effectiveness as a means of economic growth and employment-creation (which sectors are more knowledge-based than others? How much do knowledge-based sectors contribute to productivity?). This article seeks to introduce a financial inovation that would enhance a transition to a knowledge economy rather than resolve these debates about the knowledge economy per se $<<$ FootnoteThe literature is large and growing. For an excellent review of the literature and a fairly concise analysis of the prevalent debates regarding the knowledge economy, see Powell and Snellman (2004). For more recent and extensive analyses, see Dolgin (2012) and Ward (2012) >>. Powell and Snellman's (2004) insightful analysis of the nature of the knowledge economy defines it as:

\begin{abstract}
"production and services based on knowledgeintensive activities that contribute to an accelerated pace of technological and scientific advance as well as equally rapid obsolescence. The key components of a knowledge economy include a greater reliance on intellectual capabilities than on physical inputs or natural resources, combined with efforts to integrate improvements in every stage of the production process, from the R\&D lab to the factory floor to the interface with customers. These changes are reflected in the increasing relative share of the gross domestic product that is attributable to 'intangible' capital.
\end{abstract}

The knowledge economy features a number of qualities that suggest a fundamental difference from the three economic systems that preceded it; hence it is indeed a paradigm shift in economic evolution. First, it is far less influenced by time and space. Since the products and inputs are often intangible (information, skills), they can be created and used in almost any location at any time. Unlike physical products, the components of a knowledge economy have no geographic or temporal restrictions. Second, the foundations of the knowledge economy are neither bound up in the application of labor nor in that of non-human capital. Rather they are driven by human capital formation. In essence, the principal vehicles of production and value are neither physical toil nor machines, but human knowledge and ingenuity. Third, in preceding economic systems, education was bound up in the application of knowledge to specific modes of producing existing physical products and services. In a knowledge economy, education is largely geared toward generating innovation, inventions, new products and new modes of managing economic activity. Fourth, the knowledge economy is pervaded by non-rivalries in consumption. Since many of the inputs and products of the economy are intangible, they are subject to infinite and simultaneous use without depletion, hence economic relations are much less plagued with problems of limited resources. This in effect changes the very nature of economic relations: Economics is no longer about the production, distribution and consumption of goods and services in the face of limited resources. In many cases the resources in a knowledge economy are unlimited. Fifth, this non-rivalrous quality introduces another difference in the knowledge economy: There is a far greater production of public goods relative to the previous three stages of evolution because knowledge is difficult to privatize. Once new ideas are born, they can be applied virtually everywhere (Even patents commonly expire after some designated period). This would amount to a new kind of positive externality from economic activity: Products and inputs which become public domain. Sixth, unlike the three systems that preceded it, shocks in the knowledge economy are endogenous rather than exogenous. The system is designed to generate shocks, while shocks occurred as a by-product in the previous systems. These shocks have significant impacts on existing markets: They produce a faster pace of creative destruction, i.e., new ideas, products and management systems make existing ones obsolete in a faster and more comprehensive manner (think of how quickly mass air travel made other forms of transportation obsolete). The process of globalization has compounded this speed and destructive fallout of innovations. So there is the possibility for very large rewards in the short-run with innovation, but the speed of dissemination often compromises the proprietary rewards from such innovation. Seventh, innovation is driven far more by supply relative to former ages where demand was the dominant stimulant for innovation. Moreover, demand in the knowledge age is much more a function of desire than need (unlike formers ages where need played a greater role in encouraging innovation). Hence, demand for products and services in the 
knowledge economy tend to be somewhat more elastic relative to the demand for products in previous ages of economic development. The last two qualities create an economic system that is more dynamic and unstable relative to the economic systems of previous ages: Change is inherent in the system; change generates fast and pervasive change in existing markets; and finally the rewards to innovation could be great, but could also be fleeting.

According to the World Bank (2007), there are four fundamental pillars of a knowledge economy.

\section{Education and Training}

"An educated and skilled population is needed to create, share and use knowledge."

\section{Information Infrastructure}

"A dynamic information infrastructure [television, radio, telephone, internet] is required to facilitate the effective communication, dissemination and processing of information [and knowledge]."

\section{Economic Incentive and Institutional Regime}

"A regulatory and economic environment that enables the free flow of knowledge, supports investment in information and communications technology and encourages entrepreneurship is central to the knowledge economy."

\section{Innovation Systems}

"A network of research centers, universities, think tanks, private enterprises and community groups is necessary to tap into the growing stock of global knowledge, assimilate and adapt it to local needs and create new knowledge."

\section{Limitations of Present Financial Institutions in Promoting Knowledge Economies}

Present financial institutions and instruments are limited in promoting a knowledge economy. In a knowledge economy, pricing and value of knowledge products depend heavily on context. Knowledge, when locked into systems or processes, has higher inherent value than when it is in people's heads or archived on shelves of depositories and reference vaults. In a knowledge economy, labor costs become progressively less important and traditional economic concepts such as scarcity of resources and economies of scale cease to apply. Nevertheless, resources such as know-how and expertise are as critical as other economic resources.

Communication is fundamental to knowledge flows and long-term success depends on the ability to create and use knowledge faster than competitors. This is reinforced by the creation of business clusters around centers of knowledge, such as research universities and research and development (R\&D) centers, whether independent or operating under an industrial umbrella.

The majority of R\&D performed in research institutions, research universities, commercial entities, industries and manufacturing companies relies on external funding, whether from government agencies or from private finance. Exploitation of the commercial potential of any mature conceptual knowledge or transfer of technological knowledge at a high level of readiness into a commercial product requires additional investments unattainable from the traditional R\&D funding sources due to the high risk involved. The level of financial exposure is dependent on the level of maturity of the prevailing knowledge in question.

Considering government-financed R\&D projects, the finance is greatly tied to the priorities of the funding agency and accordingly can be decreased or totally slashed mid-stream or at any other stage. These situations result not only in potential loss of revenue from a lucrative market if the development span has been extended, but also drainage of the expertise that accumulated throughout the R\&D stages since the wealth of human resources has to be expunged in favor of pursuing new avenues of interest to the changing priorities of the funding source.

For example, the development of solar energy and other renewable energy sources has witnessed bursts of enthusiasm interrupted by periods of stagnation, neglect and dismantling of expert teams; as well as burying the accumulated wealth of knowledge on abandoned shelves and in historical archives. This occurred because a need for these products continued to exist, as the market in sustainable energy products persisted beyond experimental tests, prototypes and subsidized initial implementations. Some private ventures continued at lower levels but found it necessary to divert their resources to more profitable ventures of immediate return. Had there been other sources of finance available to share the risk of development of the acquired knowledge, many of the potential products could have been materialized prior to the soaring needs for alternatives to dwindling unsustainable energy sources.

Aside from funding large conglomerates and small industries to produce and supply products of national interest, government agencies often provide only seed money to help private industries prove the technical feasibility and commercial viability of specific innovations. But these industries still rely preponderantly on private funding to launch new products. In this case, the private industry has to seek finance from venture capital sources or to establish a joint venture with a large entity. Achieving that is not an easy task, especially during times of financial difficulties and uncertain economic conditions. Furthermore, venture capitalists 
often shy away from investing in areas beyond their familiarity and may require extensive business plans in excess of what the entity seeking the funds can quickly provide. On the other hand, large companies that may have the capital to invest in new ventures only participate in joint ventures that are in concert with their other areas of interest. This deprives industries not only from seeing viable concepts through to higher levels of maturity, but also may deprive those industries of the initial funds available for further development of valuable knowledge due to the scarcity of follow-on financing sources.

Meanwhile, a wealth of knowledge is abandoned or overlooked, knowledge that could generate a host of innovative ideas and concepts, inventions; and partially developed products that could meet a dire need, provide for a competitive edge and/or expand a less than competitive market. Often the owners of intellectual properties have little access to sufficient finance to carry their inventions through the necessary readiness cycle and in most situations cannot trade their knowledge for fair prices in an open market to companies that have the resources to assume the burden of developing ideas or concepts into useful products.

Knowledge output from private research institutions and research universities has been growing significantly. This trend, coupled with the General Agreement on Trade in Services (GATS), that treats education and knowledge as a commodity, has led to the establishment of institutions that open avenues for investment in higher and middle education. In addition to knowledge producing institutions, there is a new breed of industry with knowledge-intensive products and services: Knowledge-Based Organizations (KBOs), wherein knowledge forms the core of the product or service. In KBOs, knowledge is often produced and shared as a by-product of daily interactions with customers, vendors, alliance partners and even competitors; effective processes are in place to capture and share knowledge about products, customers, applications, technologies and the competitive environment; and new knowledge is created through effective application of existing knowledge. Their strategy is to change the traditional business mission from one based on selling traditional products and services to one based on the exploitation of knowledge.

\section{$I V$. The Need for a Knowledge Bourse}

A knowledge economy could be strongly enhanced through the creation of a major financial innovation: A Knowledge Bourse, within which instruments defined in terms of knowledge assets could be bought and sold. In short, it would be a market that captures the full value of human knowledge. Financial innovation has evolved in order to match investment opportunities to changes in the values of assets and methods for creating wealth. As economies have evolved and created new forms of wealth that have not theretofore been able to be packaged in investment instruments, such instruments have been created to both ascribe value to and market new assets. This has been done through processes of commodification (the ascription of value to assets that did not theretofore possess a value) and general securitization (the process through which assets could be packaged into tradable financial instruments). $<<$ FootnoteShiller (2013). This is not to be confused with the more specific current use of securitization, which is commonly used to describe the pooling of various forms of contractual debt (principally mortgages) and selling those packages as securities. General securitization represents the larger process by which all classes of assets with value are turned into tradable instruments $>>$. While many think financial innovations in investment instruments may be limited, because of the frequency with which we hear about a handful of such instruments (indexes, hedge funds, futures, options, derivatives, mutual funds), the actual number of tradable assets in the global financial market is breathtakingly large. $<<$ FootnoteTufano (2003) notes that in trying to compile a complete list of security innovations, a data vendor provided him with a staggering 1836 "security codes" (each representing a distinct financial instrument) used from the early 1980 s to $2001>>$. In fact, the process of financial innovation has shown a very long historical legacy: From Babylonian loan contracts in the second millennium B.C.C. to the recent introduction of the digital money Bitcoin. This history demonstrates that bottlenecks in economic activity frequently prompt responses in the form of new financial institutions (Goetzmann and Rouwenhorst, 2005).

Knowledge fits squarely into the issue of financial evolution for a new economy.

The value of knowledge has heretofore been poorly commodified and securitized, principally because of its intangibility. Both processes have manifest themselves more successfully for innovations in tangible assets. The market for knowledge has only partially materialized as a result of the selective commodification and securitization of intellectual property. Things such as patents, business methodologies, brand names, trademarks and trade secrets have been commodified, but have been only indirectly securitized (through the value of the companies that they belong to). There are a great many possible knowledge assets that derive from the application of intellectual human capital that have neither been commodified not securitized $<<$ Footnote In this case financial innovation would be both product and process innovation: New financial instruments (products) and new ways to deliver and price them (process) $>>$. The value of human ingenuity has been poorly ascribed and consequently the market for knowledge has been unable to realize its full potential. The extent of human knowledge and scientific discovery 
are far greater than the level of remuneration recovered by such output of human capital: The salaries of university faculties, the wages to researchers, the sale of patents, prizes for discoveries and innovation and the profits generated by corporate $\mathrm{R} \& \mathrm{D}$ all pale in relation to the true value of all manifestations of human knowledge. This is all the more disappointing given the fact that property rights have evolved extensively in the protection of intangible wealth generated by human intellectual capital. It is indeed possible under prevailing property-rights laws to capture far more remuneration for discovery and innovation than is in fact presently recovered.

There are many economic and social benefits that can be realized through the creation of Knowledge Bourses. Shiller (2012) in his Finance and the Good Society underscores the more general advantages to society from extensive investment and financial innovation. While Schiller does not consider knowledge markets, his arguments for the social benefits of financial innovation apply squarely to this area. There are major failures in the market for knowledge because the limited commodification and securitization of knowledge generate significant market distortions. These distortions limit the amount of wealth that could be created if the market for knowledge were more efficient. In this case, it is not the inability to assign ownership of the product of human capital, but in fact the lack of instruments and economic organization that would allow the market for such a product to realize its full potential. In other words, much of the value generated by human knowledge is not recoverable given prevailing financial institutions. Imagine a world full of coins that have not been converted into goods and services. This is wealth foregone. So too, much human knowledge has generated no value in conversion because of the limitations in institutions that would enhance the co-mmodification and securitization of knowledge. This is also wealth foregone. Allowing this wealth to manifest itself would bring manifold economic and social benefits. First there would be the creation of new wealth in the form of new assets and products. Second, the packaging of assets based on this new wealth would improve and deepen financial markets by creating more opportunities for investors to spread risk and solve asymmetric information problems (Schiller 2003). $<<$ FootnoteIt should be noted that a number of scholars have been critical of financial innovation. Fresh in our memory is the toxic reputation of securitization generated by the financial crisis of 2008 and of course derivatives and junk bonds have certainly also cast negative shadows on innovation. But even in the case of the recent meltdown in the market for mortgage backed assets, securitized assets in general have grown consistently from 2008 because they offer a desirable financial instrument with respect to diversification ("Back from the Dead" 2014). The financial innovation of securitization (in producing better investment assets by spreading risk and solving asymmetric information problems) has produced far more benefits than calamities (Shiller 2013). On the negative aspects of financial innovation, see for example, see Allen and Gale (1994), Bookstaber (2007), and Elul $(1995)>>$. Third there would bethe growth in the income of nations by creating markets for knowledge. Scholars have underscored the possibilities for wealth creation by political and economic institutions that promote incentives for engaging in economic activity. Financial innovations would represent just such economic institutions (North and Thomas 1973 and Acemoglu and Robinson 2012). Fourth, the greater competition in the market for knowledge would lower the cost of innovation for individuals and firms, thus increasing net gains for both kinds of economic actors (i.e., universities and corporations would not be able to monopolize new ideas). Creating the possibilities for greater market entry on the part of economic actors by new companies and consortia that produce innovations would raise the amount of investment that was formerly limited by distortions in a monopolized market. Fifth, the creation of products (like knowledge) that require small start-up costs relative to physical products (i.e., you can create a knowledge venture simply by bringing a group of minds together) would mean that gains from knowledge can be captured by all types of individuals in all types of nations: Such outcomes would go far in helping economic development among the less-affluent nations of the world (Of course, the costs could be larger if research facilities (e.g., laboratories, expensive technologies) are required). Sixth, since knowledge will produce greater possibilities for remuneration, individuals in all nations will have an incentive to develop their human capital through greater training and education. And a more specialized and educated world is a highly desirable objective. Finally, since an efficient knowledge market will maximize the level of innovation in the world, it is likely that more of the problems that face humans (environment, nutrition, disease, poverty) will be solved $<<$ FootnoteMitrany (1966) and other international functionalists believe that problems facing humans in the future will require greater technological solutions. A world of vigorous innovation is surely a recipe for creating such solutions $>>$.

Whereas there are various models for the technology readiness cycle and technology maturity levels, there are no models for knowledge maturity levels that encompass the diverse aspects of knowledge other than technology and which can be applied to determine the financial risk associated with each level of maturity as an indicator for use by investors and financial institutions in valuing knowledge and in making decisions regarding 
investments in moving a specific knowledge forward to the next level. Lack of such models deprives new forms of knowledge and innovations from potential sources of finance. Accordingly there is a need for:

- Financial instruments to make funds available for companies or research institutions attempting to transform knowledge into products that meet diverse needs, while spreading the risk among a larger base of investors

- Knowledge markets wherein trade in knowledge at different levels can take place without fear of infringements on property rights and wherein the market will determine the tangible value of knowledge

- A knowledge maturity model that identifies the financial risk associated with each level of maturity prior to transfer of the knowledge into technology, products or commodities. This is in addition to means of assigning tangible values to various forms of knowledge

\section{$V$. The Knowledge Bourse: Financial Innovation for a Knowledge Economy}

\section{General Financial Instruments}

Essentially there is a need for a Knowledge Bourse that accommodates different forms of knowledge trading and financial instruments, principle components being:

1. Knowledge stocks or equities wherein shares are issued and traded through exchanges or over-thecounter (OTC) markets to provide R\&D institutions and $R \& D$ departments of private companies with access to capital and investors with a share of ownership in the company and with potential gains based on the organization's expected future performance. This market can be split into two markets: A primary market wherein new issues are first offered and a secondary market for any subsequent trading

2. Knowledge futures wherein all contracts covering the purchase and sale of knowledge financial instruments or knowledge physical commodities or products are auctioned prior to the anticipated release date of the product to the marketplace for delivery on a specified future. A commodity/futures contract is a legally binding agreement to buy or sell a commodity of a specific quality and quantity, at a specified price at a predetermined delivery date and settlement. The infrastructure of the futures exchanges component of the Knowledge Bourse can resemble traditional futures exchange markets such as the Chicago Mercantile Exchange
3. Knowledge spot market, "knowledge cash market" or "knowledge physical market", wherein prices are settled in cash on the spot at current market prices, as opposed to forward prices. The market includes: (1) Knowledge commodities or knowledge securities markets in which new goods generated from knowledge are sold for cash and delivered immediately. Contracts bought and sold on these markets are immediately effective. (2) Knowledge futures transactions for which knowledge commodities can be reasonably expected to be delivered in one month or less. A spot market can be an organized market, an exchange market or OTC. Spot markets can operate wherever the Knowledge Bourse infrastructure exists to conduct the transaction. The knowledge spot market for most instruments can exist primarily on the Internet

4. Knowledge Initial Public Offerings (KIPO) that represent the first sale of knowledge stocks by a private company or institution to the public, which can be issued by smaller, younger R\&D organizations seeking the capital to expand, but also by large privately owned R\&D organization such as a research institution or research universities looking to become publicly traded. In a KIPO, the issuer obtains the assistance of an underwriting firm, which helps it determine whether to issue common securities or preferred securities, the best offering price and the time to bring it to market. (KIPOs can be an expecially risky investment. For the individual investor, it is difficult to predict what the stock will do on its initial day of trading and in the near future because there is often little historical data with which to analyze the organization, especially if it's main product is knowledge. Also, many of the KIPOs will be from institutions going through a transitory growth period, which are subject to additional uncertainty regarding their future values)

In addition to the above, there is a need for development of novel trading approaches in the Knowledge Bourse to facilitate its operation. This is in addition to adaptation, modification or direct adoption of traditional trading methods, tools and roles currently employed in stock and futures markets.

Share prices of companies traded in a stock exchange market reflect activities such as new discoveries that may lead to a successful line of products or the release of a new product and the success of the product in penetrating markets of similar products. In other words, new knowledge boosts a company's position in the financial market. Usually such events and the preceding R\&D activities do not require offering special classes of stocks. However, established companies can protect their stock from drastic fluctuations associated with success or 
failure of introducing new products based on ongoing R\&D activities by offering a separate stock or class of stock specially designed to finance the development of each major product until reaching a stable position in the market. Exemplary embodiments provide for such special stock to be absorbed by the company's major stocks when price has stabilized.

Entrepreneurs form companies based on the exploitation of a novel idea or invention to develop specific products with the prospective of meeting an existing need of a specific consumer sector or an existing demand in the marketplace. However, entrepreneurs lack the resources for financing their ventures without surrendering their intellectual property to an established organization or investor until a buyer is interested in realizing its potential. By accessing a stock market specialized in high risk ventures, they can fund the process of converting their inventions into tangible products that have high potential in the marketplace through design and demonstration of prototypes, thus effectively limiting development risks by taking the final steps to produce a working technology that passes extensive field tests or produces full-fledged products. Once the products are established and the company has a business niche in the marketplace, the company may be acquired or its stock may be traded in the traditional stock market.

R\&D institutions, $R \& D$ divisions in established companies and R\&D arms of research universities and higher education establishments are in continuous and exhaustive pursuit of public grants and research contracts. Competition among the many for limited resources diverts efforts from development to grant hunting and diverts creative energy to knowledge sustenance. Concurrently, unique timely concepts and serious initiatives to solve urgent problems may fall through the cracks and never surface again. Even in cases of successful acquisition of public finance, uninterrupted continuation until achievement of an R\&D objective is not guaranteed regardless of the degree of success in reaching the program goals. Often enough the amount of the grant or support is not sufficient to seriously pursue the stated program goals.

Since competition for funds is among diverse ideas, ideas that are funded are not necessarily the most likely to succeed since selection criteria do not necessarily relate to the likelihood of success. An organization may be able to acquire funds from the financial market through an initial public offering in a special stock market such as a Knowledge Bourse to finance a multicomponent program that involves a variety of projects. Success of some projects in developing a marketable product can offset losses in other programs that involve higher levels of risk.

Alternatively, a group of research institutions or R\&D organizations may wish to group their resources and issue special stocks in a Knowledge Bourse to fund their R\&D programs. The group would join forces, share resources and collaborate in issuance of a joint prospective detailing their programs and the risk associated with their collaborative financial scheme. The financial instrument thus created would have lower risk on average compared to individual issuance of stocks and would reduce the financial burdens of issuance of the special knowledge stock. The joint special knowledge stock would be similar to joint ventures among the investors. Such joint ventures can operate on a global level while maintaining the competition between the participating $R \& D$ constituents.

Special financial instruments can be specifically developed and introduced for trading of several new knowledge-related financial products in the Knowledge Bourse, such as the value of exceptional human assets in an R\&D organization that add value to the activity of the organization. For example, the presence of Noble Laureates on the faculty or team of a research institution is likely to attract high caliber researchers as well as highly funded R\&D projects. Such a product does not represent just the human capital of an individual or individuals, but rather an asset based on their contribution to the productivity of the organization: i.e., the potential for the acquisition of funding contracts and grants, innovations, inventions, moving knowledge across transitional levels to actual production of goods or services, among other things.

Examples of stocks to be traded in the Knowledge Bourse are shares in Knowledge-based industries and Knowledge-based organizations that supply products/services such as, but not limited to:

- Printed /Electronic Products/Services: For example, books, newspapers, syndication articles, periodicals, manuscripts, forms and templates, policies/regulations, business plans and processes/procedures; training manuals and practitioner's guides; statistics and qualitative/quantitative data, etc

- Audio/Video Products/Services: For example, movies; songs; plays; books; TV shows, episodes and programs; documentaries on variety of topics covering education and/or entertainment, etc.

- Internet-Based Products/Services: For example, eBooks, self-paced educational and training courses delivered online, interactive eLearning products, statistics/data (qualitative and quantitative), audio/video products/services, information, etc

- Software Products/Services: For example, open source software, applications software, software development and testing tools, operating systems, computer codes, legacy computation programs, etc. 
- Methods/Tools Products/Services: For example, methods /frameworks, tools, conceptual and analytical tools and models, simulations, applications, indicators, databases, bibliographies, proprietary information, best/leading practices; patents, etc

The architecture of the Knowledge Bourse is outlined in Fig. 1 and it represents a full set of rules governing the activities associated with the Knowledge Bourse value chain. Data Dissemination is the act of transmitting preand-post trade data about quotes and trades respectively to market participants. Order Routing is the act of delivering orders from their originators, such as investors and financial intermediaries, to the execution mechanism. Order Execution is the process whereby orders can be transformed into trades. Matching is the act of a third-party broker matching buyers with sellers within the stock market. Based on the needs of the buyer, the broker finds the right stock for the buyer to invest in. Clearing is an entity of the stock exchange through which settlement of equities happens. The details of all transactions performed by the brokers are made available to the Clearing House by the stock exchange. The Clearing House gives an obligation report to brokers and custodians who are required to settle their money/securities obligations with the specified deadlines, failing which they are required to pay penalties. This obligation report serves as a statement of mutual contentment. The Settlement is what happens after a broker has bought or sold shares. There are two aspects to the Settlement: Transfer of ownership (i.e., the delivery of what has been bought and sold) and the payment for the shares or other security. Settlement cycle is the period in which equities are traded in the exchange. At the end of this Settlement cycle period, the obligations of each broker is calculated and the brokers then settle their respective obligations according to guidelines, laws and regulations institutionalized by the clearing agency.

Figure 2 presents a variety of possible knowledge securities that can be offered in existing world-wide financial markets. $<<$ Footnote However, in the application of the Knowledge Bourse in Saudi Arabia or under the umbrella of Islamic financial institution adhering to the Sharia (Islamic Jurisprudence) several securities are not allowed. Generally, investment in Islam is like trading in goods in monopoly-free open markets wherein there is an element of risk involved. Any financial instrument with a fixed rate of return is absolutely forbidden. The allowed securities are those with values that follow the fluctuations of knowledge-based products, commodities and services in the market; wherein there is no limit on profits or losses. $>>$

Tradable assets will consist of three broad types of instruments: Knowledge Equity Securities, Knowledge
Debt Securities and Special Knowledge Financial Instruments. Knowledge Equity Securities comprise Knowledge Common Stocks, Knowledge Preferred Stocks, Knowledge Tracking Stocks and Knowledge Warrants. This stock variety represents an ownership interest in a publicly traded knowledge-based corporation or institution looking for future growth and requires money to invest to transfer knowledge into a final usable and profitable knowledge product/service. A share of knowledge stock represents ownership in a knowledge-based corporation or institution and is evidenced by a stock certificate. For a newly listed knowledge-based company, the stock price is estimated by the issuing entity as the offering price. For an existing publicly traded knowledge-based company, the price at which additional equity is issued is usually based on the current market price. The number of knowledge stock shares a knowledge-based company sells depends on the amount of equity capital the knowledge-based company requires and the price of each share it sells.

Knowledge Common Stocks are knowledge securities representing equity ownership in a knowledgebased organization, entitling the holder voting rights and a share of the company's success through dividends and/or capital appreciation. For a publicly traded knowledge-based organization to raise equity it issues Knowledge Common Stocks at a price the market can bear. In the event of liquidation, knowledge common stockholders will have rights to the knowledge-based company's assets only after bondholders, other debt holders and preferred stockholders have been satisfied.

Like Knowledge Common Stocks, Knowledge Preferred Stocks represent partial ownership in a company with no voting rights. However, Knowledge Preferred Stocks earn fixed dividends that are paid before any dividends are paid to Knowledge Common Stock holders and those dividends do not fluctuate. The company does not have to pay this dividend if it lacks the financial ability to do so. Knowledge Preferred Stocks will take precedence over Knowledge Common Stocks in the event of liquidation.

Preferred stocks are generally considered a less risky investment than traditional common stock, but also they usually offer lower potential rates of return. Most preferred stocks guarantee dividends. In this way, preferred stocks have a guaranteed performance similar to bonds. Accordingly, these very characteristics and more make this type of stock non- Sharia compliant and hence is regarded as a haram (forbidden in Islam) investment tool. That is, it cannot be issued or bought in Saudi Arabia and cannot be traded in Islamic financial institutions. 


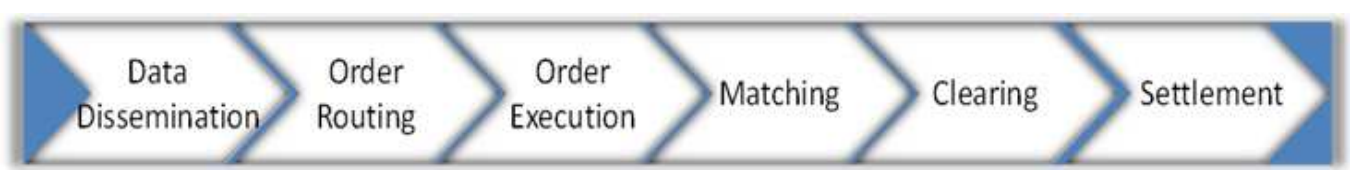

Fig. 1. Knowledge Bourse operational architecture

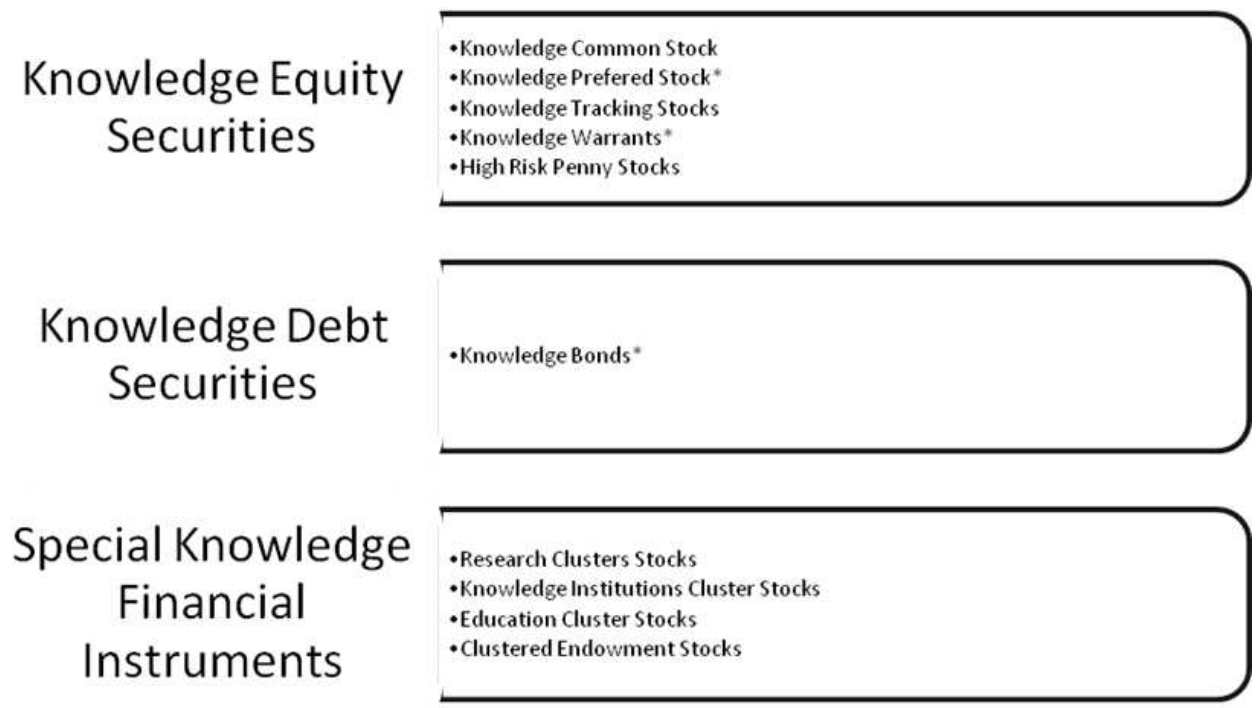

*Prohibited in Islamic Economic Systems

Fig. 2. Knowledge securities

Knowledge Tracking Stocks are a special class of common stocks issued by a parent company that track the performance of a particular knowledge product/service without having claim on the assets of a division or the parent company. When a parent company issues a Knowledge Tracking Stock, all revenues and expenses of the applicable knowledge product/service are separated from the parent company's financial statements and bound to the Knowledge Tracking Stock. Knowledge Tracking Stocks trade as separate securities. As a result, if the unit or division does well, the value of the tracking stock may increase even if the company as a whole performs poorly; the opposite may also be true. Knowledge Tracking Stocks will make it easier for companies to raise capital for specific knowledge product/service instead of spinning off the line of business into a separate company. Keeping companies together allows management to take advantage of synergies and efficiencies. Managing two classes of stocks with one set of assets requires that specific controls are in place to avoid conflicts for corporate managers and directors.

Knowledge Warrants are securities issued by a company that provide the holder with the right to buy a share of stock in the company at a fixed price during the life of the warrant. The advantages of warrants are that they are priced based on the volatility assigned to the underlying stock--the greater the volatility, the greater the value. Warrants by themselves create no financial obligations at the time of issue. Consequently, issuing warrants is a good way for a high-growth firm to raise funds, especially when current cash flows are low or negative. Warrants do not create any new additional shares while they raise equity investment funds for current use.

A 'Warrant' is a derivative security that gives the holder the right to purchase securities (usually equity) from the issuer at a specific price within a certain time frame. Warrants are often included in a new debt issue as a "sweetener" to entice investors.

Knowledge Debt Securities constitute any debt instrument that can be bought or sold between two parties and has basic terms defined, such as amount borrowed, interest rate and maturity/renewal date. Debt securities include Knowledge Bonds. The interest rate on a debt security is largely determined by the perceived repayment ability of the borrower. Higher risks of payment default, for example, almost always lead to higher interest rates to borrow capital. Most debt securities are traded over-the-counter, with much of the trading now conducted electronically. Knowledge Debt securities on the whole are safer investments than equity securities, but riskier than cash. Debt securities get their measure of safety by having a principal amount that is returned to the lender at the maturity date or upon the 
sale of the security. They are typically classified and grouped by their level of default risk, the type of issuer and income payment cycles.

Knowledge Bonds are a debt instrument issued for a period of more than one year with the purpose of raising capital by borrowing. Generally, a Knowledge Bond is a promise to repay the principal along with interest (coupons) on a specified date (maturity). Some bonds do not pay interest, but all bonds require a repayment of principal. When an investor buys a bond, he/she becomes a creditor of the issuer. However, the buyer does not gain any kind of ownership rights to the issuer, unlike in the case of equities. On the other hand, a bond holder has a greater claim on an issuer's income than a shareholder in the case of financial distress. $<<$ Footnote Bonds by definition are forbidden by Sharia laws. The rule is that money cannot make money without the exchange of goods or commodities having tangible value. $>>$

Since many small public companies are engaged in business activities that can be classified as knowledge or knowledge related ventures. High risk, low priced "Penny Stocks" can be used by emerging knowledge organizations to finance realization of an invention, group of inventions or bringing a new knowledge-based product to the market. Penny Stocks are common shares of small public companies that trade below $\$ 5$ per share in the USA ( $£ 1$ in the United Kingdom), are not listed on a national exchange, fail to meet other criteria specific to regular common stocks and are often traded Over-The-Counter (OTC). In the United States, the Securities and Exchange Commission (SEC) and the Financial Industry Regulatory Authority (FINRA) regulate the sale of penny stocks.

\section{Special Financial Instruments}

Special Knowledge Financial Instruments comprise Research Cluster Stocks, Knowledge Institutions Cluster Stocks, Education Cluster Institutions Stocks, Clustered Endowment Stocks and different variations on those stocks. These may be defined as follows:

- Research Cluster Stocks: A special stock wherein the instrument is used to finance a bundle of $R \& D$ projects at different stages of knowledge maturity, wherein the mix provides an acceptable level of risk and guarantees long term growth in terms of bringing successive knowledge-based products to the marketplace and continuously transforming bleeding edge technologies to leading edge technologies. Those types of stocks can be in the form of venture capital for finance of a specific research field or for financing a group of patents of similar nature. The instrument is considered a form of joint venture

- Knowledge Institutions Cluster Stocks: Similar to the Research Cluster Stock with the difference being that the cluster is formed by multiple institutions engaged in transfer of technology from basic and applied research to leading edge technologies, thus generating royalties on intellectual properties

- Education Institutions Cluster Stocks: Similar to the Research Cluster Stock with the difference being that the cluster is formed by multiple institutions engaged in higher education and private research universities

- Clustered Endowment Stocks: Stocks invested in notable scholars and scientists in R\&D institutions whose presence attracts public and private $R \& D$ funds to research institutions. That type of stock is purchased by donors for selected beneficiaries and the return from the investments goes to the research institutions

Additional instruments include mutual funds which include a portfolio of investments in different stocks to minimize the risk. Example of Sharia compliant mutual funds is the Amana Mutual Funds Trust, a mutual fund company offering investment products consistent with Islamic banking principles, headquartered in Bellingham, Washington, USA. The Amana Funds are managed under the "value investment style" and under strict guidelines to comply with Islamic principles. Unlike most traditional mutual funds they do not contain securities that are forbidden by Sharia law (Graham, 2004).

\section{Trading}

Figure 3 depicts the trading process in the Knowledge Bourse: Trading is Automatic, Manual, or Internet-based.

Generally, some traders-especially those with good intuition about the market-will prefer to adopt their own trading strategies based on comprehensive research about the market and trade manually. The quickest way for a novice to learn about the market is to engage in manual trading, which enables a trader to open or close his market position whenever s/he chooses.

The most obvious benefit of automated trading is that it frees traders from time constraints by making the practice of constantly watching the market unnecessary. If a change in the market occurs when a trader is indisposed, the automated trading system will execute the buy and sell orders that have been specified earlier. Furthermore, automated trading prevents fear and greed from affecting traders' decisions. In automated trading, however, computer algorithms replace the human element. 
In the Knowledge Bourse, automated trading makes use of computer programs for entering trading orders with the computer algorithm deciding on aspects of the order such as the timing, price, or quantity of the order, or in many cases initiating the order without human intervention. In addition, automated trading is likely to be used by institutional traders to divide large trades into several smaller trades in order to manage market impact and risk.

In the Knowledge Bourse, knowledge stock traders need to become more proactive to ensure that the underlying algorithmic strategy is consistent with their investment objectives. The automated trading process comprises several steps, including Pre-trade Analysis, which provides the necessary data to make informed algorithmic trading decisions as well as insight into potential risk reduction and hedging opportunities to further improve execution. Pre-trade Analysis also provides investors with liquidity summaries, cost \& risk estimates, as well as trading difficulty and stability measures to determine which orders can be successfully implemented via algorithmic trading and which orders require manual intervention in addition to the necessary data to develop views for short-term price movements and market conditions.

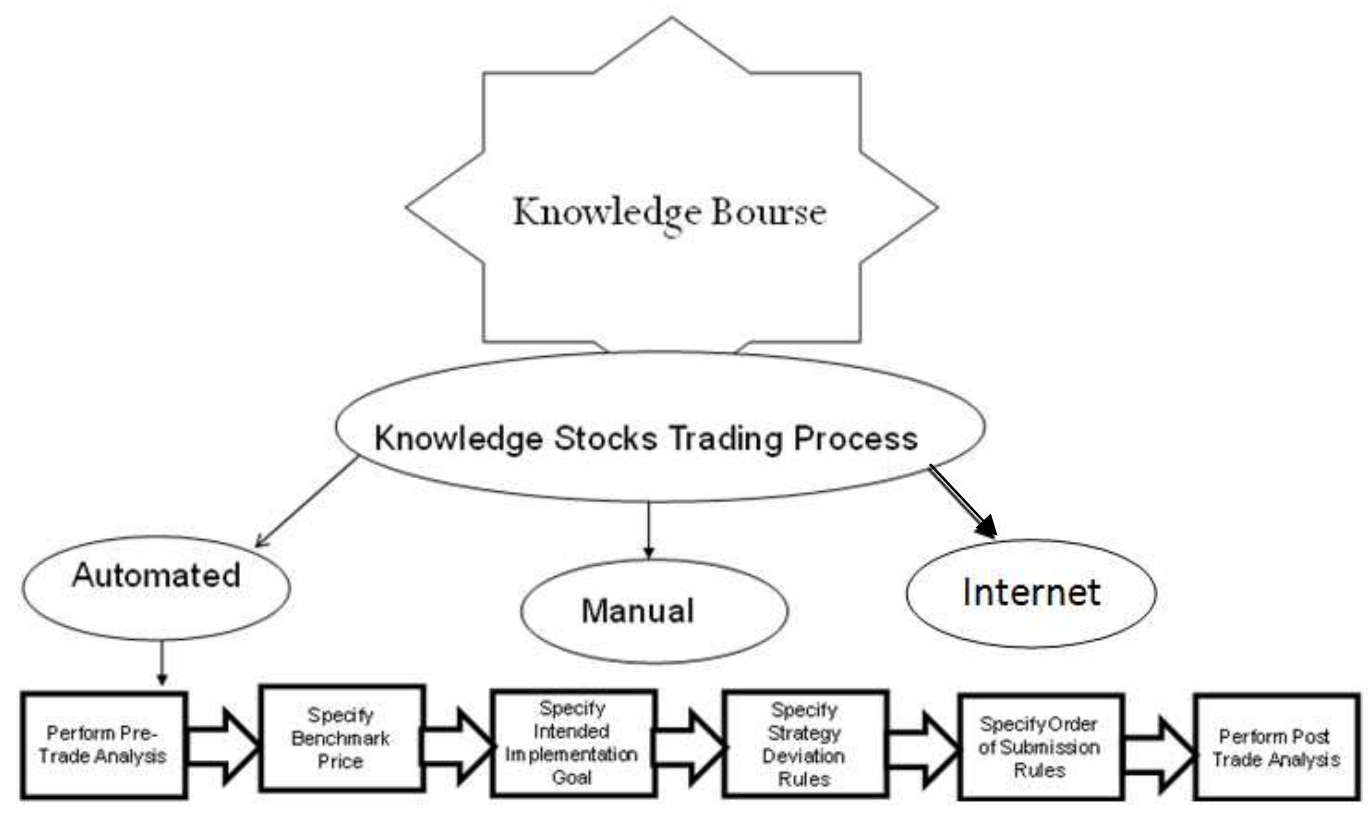

Fig. 3. Trading procedures for knowledge assets

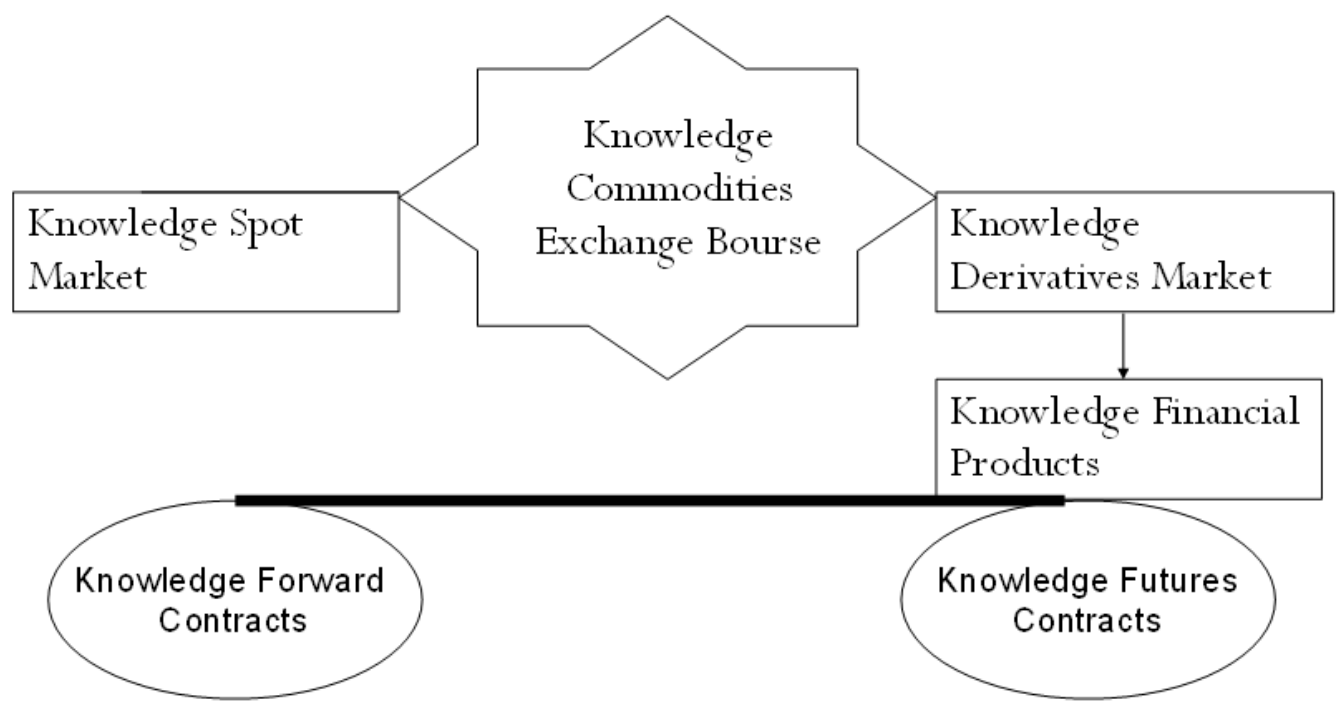

Fig. 4. Knowledge commodities exchange bourse 
A second step in the automated trading process is to Specify a Benchmark Price. The benchmark price is investor specific. Furthermore, the same investor may specify different benchmark prices for identical orders on different days if the investment objectives have changed and can be categorized into pre-, intra-and post-trade prices:

- The pre-trade benchmark prices are those prices that are known before or at the time trading begins. These include the investment decision price, previous night's closing price, opening price and arrival price

- Intra-day benchmarks are comprised of those prices that occur during trading

- Post-trade benchmarks include any price that occurs after or at the end of trading, the most commonly of which being the day's closing price

A third step in the automated trading process is to Specify an Intended Implementation Goal, which relates to the level of trading aggressiveness or passiveness. Aggressive trading is associated with higher cost and less risk while passive trading is associated with lower market impact and higher risk. This market phenomenon gives rise to the trader's dilemma: Trading too aggressive will lead to higher impact cost, but trading too passively will lead to higher risk and may result in even more costly trades. Therefore, the implementation goal is to solve the trader's dilemma. The solution is found by balancing the tradeoff between cost and risk based at the investor specified level of risk aversion. The benchmark price is investor specific and may in fact be different for two investors with identical trade lists. For example, a value manager may desire execution at their decision price (i.e., the price used in the portfolio construction phase), a mutual fund manager may desire execution at the closing price to coincide with the valuation of the fund and an indexer may desire execution that occurs on different days if the investment objectives have changed.

Another step in the automated trading process is to Specify Strategy Deviation Rules that define how the algorithm should deviate from the originally prescribed optimal strategy and implementation goal. In specifying the appropriate deviation strategy, it is important to have a complete understanding of how the deviation rule impacts the cost distribution. In times of adverse momentum, the deviation strategy may be more costly than a strategy without any specified deviation rule. Additionally, it is possible to develop deviation rules that further minimize the potential for large losses with an increase in potential for gains, but this comes at an increased cost. It is essential that traders understand the impact of the decision on the cost distribution.

In the automated trading process it is necessary to Specify the Order of Submission Rules that refer to the actual market pricing schemes (e.g., market or limit order), share quantities, wait period between order submissions, revisions and cancellation. The more common pricing rules include market and limit orders (all variations thereof) as well as floating prices that are pegged to a reference price such as the bid, ask, or midpoint, and change with the reference price. Varying these order types allows the algorithm to adhere to the optimally prescribed strategy by executing aggressively (i.e., market orders) and/or passively (i.e., limit orders) when needed. The use of an algorithm when submitting marketable orders affords a degree of anonymity and does not highlight the type of order being entered. In most situations it is appropriate to combine limit, market, floats and reserve orders.

The automatic trading also involves Performing Post Trade Analysis. Algorithmic post trade analysis is a two part process that consists of cost measurement and algorithm performance analysis. Cost is measured as the difference between the actual realized execution price and the specified benchmark price. This allows investors to evaluate the accuracy of the trading cost model to improve future cost estimates and macro strategy decisions, and it provides managers with higher quality price information to improve investment decisions. Algorithmic performance is analyzed to assess the ability of the algorithm to adhere to the optimally prescribed strategy, its ability to achieve fair and reasonable prices and determine if the algorithm deviates from the optimally specified strategy in an appropriate manner. Investors must continuously perform post-trade analysis to ensure brokers are delivering as advertised and question those executions that are out of line with pre-trade cost estimates.

\section{Knowledge as a Commodity}

Figure 4 shows the structure of a knowledge commodities exchange bourse that resembles traditional commodities exchange markets with appropriate modifications in accordance with exemplary embodiments of the present model. Knowledge commodities are knowledge products/services which have been proven to have a value in the past, need to transfer the ownership to new ownership to continue using it in the same way or create a new use for it. Furthermore, knowledge commodities are goods for which there is demand and are supplied without qualitative differentiation across a market.

The Knowledge Commodity Exchange Bourse facilitates trading in various knowledge commodities through a spot or a derivatives market. In a Knowledge Spot Market, knowledge commodities are bought and 
sold for immediate delivery. In a Knowledge Derivatives Market, various Knowledge Commodity Bourse Financial Products or financial instruments based on commodities are traded. The Knowledge Commodity Bourse Financial Products include Knowledge Commodity Forward Contracts and Knowledge Commodity Futures Contracts. To maintain the futures prices in line with the spot market, the bourse will include provisions for settlement of contracts by physical delivery and ensuring that the futures and spot prices coincide during the settlement so that the fair price discovery mechanism is in place.

Knowledge Commodities Spot Trading represents any transaction where delivery either takes place immediately, or within a minimum lag between the trade and delivery due to technical constraints. Knowledge Commodities Spot Trading most often involves visual inspection of the commodity or a sample of the commodity and is carried out in markets such as wholesale markets. Knowledge Commodities Spot Trading also requires the existence of agreed standards so that some trades can be made without visual inspection.

The Knowledge Commodity Forward Contract is a nonstandardized contract between two parties to buy or sell a knowledge product/service at a specified future time at a price agreed today. Forward contracts are not bourse-traded. It costs nothing to enter a forward contract. The party agreeing to buy the underlying knowledge product/service in the future assumes a long position and the party agreeing to sell the asset in the future assumes a short position. The price agreed upon is called the delivery price, which is equal to the forward price at the time the contract is sold. Forward contracts can be used to hedge risk, as a means of speculation, or to allow a party to take advantage of a quality of the underlying instrument that is time-sensitive.

The Knowledge Commodity Futures Contract is a standardized contract between two parties to buy or sell a specified knowledge product/service of standardized quantity and quality at a specified future date at a price agreed today (the futures price). The futures contracts are traded on the Knowledge Commodity Exchange Bourse. The party agreeing to buy the underlying knowledge product/service in the future assumes a long position and the party agreeing to sell the knowledge product/service in the future assumes a short position. The price is determined by the instantaneous equilibrium between the forces of supply and demand among competing buy and sell orders on the exchange at the time of the purchase or sale of the contract. The future date is called the delivery date or final settlement date. The official price of the futures contract at the end of a day's trading session on the Knowledge Commodity Exchange Bourse is called the settlement price for that day of business on the bourse.
Based on current practices in the commodity market dealing with virtual commodities which cannot be delivered, such contracts are not allowed in Sharia law and by the way such instruments were the major factorsin the financial crisis of 2008, where large banks and economies suffered endless losses. However, the investment in the future development of an existing knowledge into a knowledge-based product that can be delivered or moved from one location to the other is an exception to this law.

The differences between Industrial Commodities and Knowledge Commodities are as follow (see Table 1).

The relationship between the Knowledge Commodity Exchange and the Knowledge Stock Exchange with traditional commodity and stock exchanges will be characterized by competition and collaboration.

Certain factors will increase competition between the different branches of the Knowledge Bourse and the existing stock and commodity exchanges:

- Potential Profits: The possibility of obtaining sufficient profits will provide an incentive for private firms to compete with the Knowledge Bourse in the provisions of some of their functions

- Diversity of Trading Objectives: A diversity of preferences among investors for different trading objectives will give an incentive for market participants to develop different trading systems to satisfy these diverse preferences

- Legal Impediments: The intensity of competition between trading systems may be influenced by the pressure of legal impediments and governmental regulations

- Economies of Scale: Economies of scale arise in the management of trading systems if the cost per trade of operating the system declines as the number of trades executed on the system increases. Advances in technology have lowered the cost of building trading systems as a result of the economics of scale, and make it easier for the new Knowledge Bourse to enter the market for trading systems. The existing exchanges with historically high costs are at a competitive disadvantage

- Network Externalities: Existing exchanges are likely to benefit from a positive network externality with the Knowledge Bourse. The likelihood of a trader receiving an execution of his order on an exchange is higher if the other traders already send their orders to the exchange. Order flow attracts the flow of orders and a trading system with a large number of orders has an advantage over a new market

- Enhancements in order routing facilities: Enhancements in the Knowledge Bourse order routing facilities and the ease of submitting contingent orders to many markets will affect market participants' 
willingness to establish trading systems that compete with existing exchanges. As the direct switching costs to investors of diverting their order flow away from an existing market to a newly developed Knowledge Bourse become lower, with advances in information technology, so investors become more disposed to consider using the Knowledge Bourse as an alternative trading system

In terms of cooperation among the components of the Knowledge Bourse and traditional exchange markets, there are many ways in which the Knowledge Bourse can affect a linkage, joint venture, or merger with another exchange's contractual procedures by which shared delivery of services can be implemented. Any subset of the various functions undertaken by the Knowledge Bourse and other exchanges can be shared, including Marketing, Listing, Order Routing, Information Dissemination, Order Execution, Matching, Clearing, Settlement and Administrative Services. Furthermore, there are many aspects common to most cooperative exchange projects including reduction of costs and thus gaining on average over competitors. For example, economics of scale may be available to both exchanges, linkage between futures markets may reduce the costs of maintaining off-setting positions on both exchanges and a linkage may also allow cooperating exchanges to benefit from the network externality associated with the attraction of order flow. New technology is important to enhance the network externality the traditional exchanges may obtain by establishing a market linkage between themselves and the Knowledge Bourse, assuming the exchange has a compatible technology.

\section{Management}

Figure 5 depicts the governance organization of the Knowledge Bourse. Good governance is a critical ingredient of sound capital markets since it manages the system by which the corporation is directed, controlled and held accountable. It is the system by which the legitimacy, relevance and compliance of the corporation is monitored, supervised and regulated. It is the set of self-regulatory mechanisms by which the corporation governs and conducts itself to ensure that it remains legitimate, viable and competitive. The
Knowledge Bourse will adopt a clear and transparent corporate governance framework for which it will provide adequate disclosure.

The issues affecting the governance of the Knowledge Bourse include Listing Rules, which comprise a set of regulations applicable to any company listed on the Knowledge Bourse, subject to the oversight of the Regulator. The Listing Rules will set out mandatory standards for any company wishing to list its shares or securities for sale to the public on the Knowledge Bourse, including principles on executive pay and the requirement to comply or explain noncompliance with the corporate governance code, the requirements of information in a prospectus before an initial public offering of shares, new share offers, rights issues, disclosure of price sensitive information, or takeover bids for companies.

Listing requirements specify the relationship between the Knowledge Bourse and the issuer and govern the standards expected of the issuer and its directors. Listing Rules are crucial to controlling the standard of disclosure and code of conduct of companies offering public securities. The Regulator and the Knowledge Bourse will define the responsibilities and obligations of the listing company in connection with the trading of their issued and outstanding securities in the listing market. In cases where the Regulator and the Knowledge Bourse share listing responsibilities, it will be completely clear to market participants where each step in the decisionmaking process lies, including the ultimate decision in the listing process. Listing rules will be reviewed and approved, and standards monitored by the Regulator.

The Regulator and the Knowledge Bourse will formulate and publish appropriate listing rules. The respective responsibilities of the Regulator and the Knowledge Bourse in the listing process will be fully transparent. Requirements such as the listing procedures, time scheduling for processing of the listing dossier, costs for the issuer and minimum size of capitalization will be compiled in a single rulebook, the "IPO Process Book," which will be publicly available.

Table 1. The differences between Industrial Commodities and Knowledge Commodities

\begin{tabular}{|c|c|c|}
\hline & Industrial Commodities & Knowledge Commodities \\
\hline Product type & Physical goods & Virtual products \\
\hline Product Examples & Agriculture products and metals & Operating System Software Disk, Movie Disk/Tape \\
\hline Design/Development & Simple & Complex and time-consuming task \\
\hline Production Effort/Resources & $\begin{array}{l}\text { Each new product will take resources } \\
\text { to manufacture it }\end{array}$ & Can be copied for almost zero cost \\
\hline Trade-off & Between quality and quantity & Between quality and time \\
\hline Production Time & $\begin{array}{l}\text { The amount of products created is } \\
\text { limited by the time it takes to } \\
\text { manufacture each product }\end{array}$ & $\begin{array}{l}\text { No need to invest time to create } \\
\text { copies of the product; instead, } \\
\text { invest time into making the product better }\end{array}$ \\
\hline
\end{tabular}




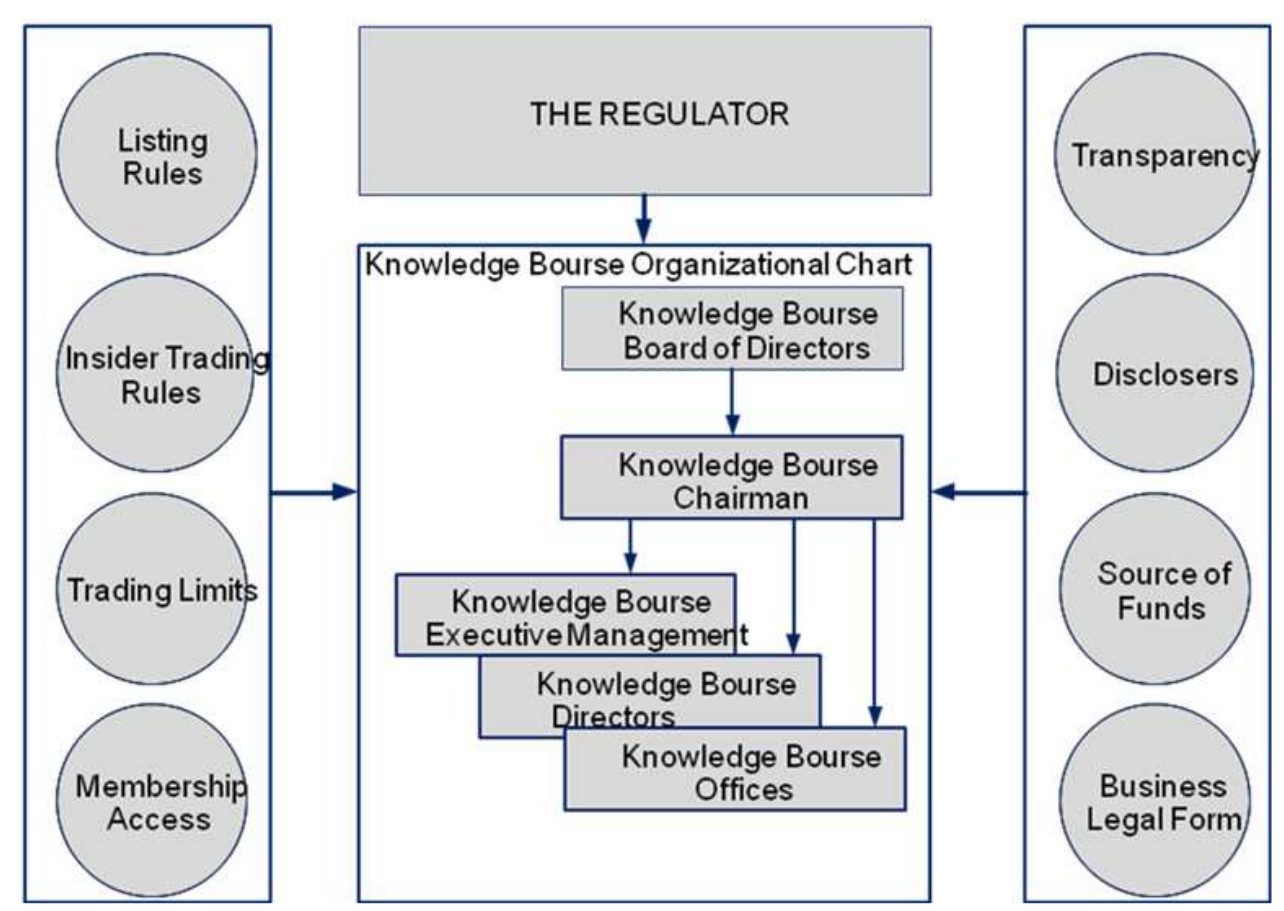

Fig. 5. Knowledge Bourse governance

As an example of Listing Rules, the South African government encourages overseas-controlled companies to seek a listing on the Johannesburg Stock Exchange (JSE) and so provide the public with an opportunity to obtain a stake in the equity of companies trading in South Africa. Applications for listing are made to the Manager (Listings) of the Securities Exchange and must be submitted through a sponsoring broker. A number of requirements must be met before a company's application for a listing will be accepted. The requirements for listing on the main board include the following:

- A subscribed capital of at least R1 million in the form of at least 1 million shares in issue

- A holding by the public of at least 30 per cent of the first million shares and an agreed percentage of the balance. There should be no fewer than 300 shareholders

- A satisfactory profit history for the past three years with a current audited profit level of at least R1 million before tax. Exceptions are made in special circumstances and in the case of newly formed mining companies

Required are an approved memorandum and articles of association (articles of incorporation and bylaws) of the parent and any subsidiary companies--no application for a listing will be considered otherwise. These documents must comply with the requirements of the JSE, which are detailed in a booklet published by the
Securities Exchange entitled, "Requirements for Memoranda and Articles of Association." The listing of management, founder, or any other classes of shares ensuring control of a company by a small group of shareholders will not be permitted.

Insider Trading Rules are defined as the rules governing a specific prohibited activity. Insider dealing occurs where a privileged insider, such as an officer or professional adviser who has unpublished, material, price-sensitive information about securities gained by virtue of his/her relationship with the company, exploits that information to make a profit or avoid a loss by dealing in the securities, the price of which would have been materially altered if the information had been disclosed. The securities regulator normally sets rules to prevent insider trading and market manipulation and relies on the market to implement the rules. The Knowledge Bourse will set detailed Insider Trading regulations based on the Regulator's rules. The Regulator and the Knowledge Bourse will have at its disposal a variety of sanctions and penalties to be imposed on intermediaries to address improper conduct. The sanctions and penalties will be used in a proportionate manner and will be subject to review and appeal via a procedure of due process. The range of sanctions and penalties will cover administrative, civil and criminal remedial measures. Examples of sanctions imposed by the Regulator or the Knowledge Bourse include:

- A warning

- A reprimand in private or by way of public statement 
- A fine, as stipulated by law or in a contract with the capital market

- A public statement of censure

- The imposition of conditions on the operations of the firm, its principals, or employees

- The temporary suspension of the member firm or any of its executives from all Knowledge Bourse facilities for a defined period

- The termination of membership in the Knowledge Bourse and dealer association

- A recommendation by the Knowledge Bourse to the Regulator that the license of a member be suspended

- The transmission of the file to the judicial authorities for action under criminal law

- The termination of the firm's license

As for Trading Limits, the Knowledge Bourse will be protected by the rules that prevent a listed knowledge share from trading on another market or from trading at all off the market (i.e., over the counter). Investors benefit from the disclosure of information about all trades as they occur and the market's rule ensures this by requiring all trades to take place on the market. Trading on a market is more transparent and better priced than trades off a market. The rule allows a critical mass of shares for trading by consolidating order flow, which makes the bourse more efficient. Listing on many markets would dilute the market for the security.

Regarding Membership Access, the Knowledge Bourse will be treated as a firm and will prosper by a strategy that limits access to membership. The Knowledge Bourse Governance structure will be a Commercial Mutual Nonprofit Firm that is controlled by and run for the consumers of the firm.

Transparency about pricing and volume is critical to a well-functioning Knowledge Bourse. Part of the Knowledge Bourse will run as an electronic auction market and will publicise all trades immediately. Another part of the Knowledge Bourse will run as a dealer market that will permit a delay for block trades subject to strict rules. Some block trades are so big that a dealer, who reveals or even suggests the large size of the trade before obtaining counter parties, would change the market price of the stock to his or her disadvantage. The Knowledge Bourse rules, regulations and operations will be clearly expressed, understandable and readily available to anyone who needs to use them and will be founded on legislative provisions. The rules of the Knowledge Bourse will be applied equally to all participants without favor or discrimination.

The Knowledge Bourse will observe standards of fairness and confidentiality when exercising powers and delegating responsibilities. The Knowledge Bourse will ensure that the exercise of the self-regulatory power is in the public interest and results in fair and consistent enforcement of applicable securities laws and regulations. Knowledge Bourse rules will apply to a wide variety of activities: Admission to trading, listing, integrity and conduct in the market, service providers to the market, relationships with customers, complaints, procedures for disputes and arbitration, and discipline. Knowledge Bourse rules will ensure a high standard of conduct in the following fields: Licensing, surveillance, enforcement and discipline, standards of integrity for broker-dealers and other market participants, and conduct of business of firms.

In terms of Disclosures, the Knowledge Bourse regulations/procedures will address several questions: What must be disclosed? How specific must the disclosure be? How is the information disclosed? Who frames and enforces the disclosure rules? It will be necessary to balance the shareholder's need for transparency against the issuer's cost of supplying the information. Assembling the data, publishing it, distributing it and keeping it up to date is expensive.

The Regulator may elect to reduce the cost of disclosure for the listed company and accept that the investor will be less protected. The Knowledge Bourse has an important role to play in ensuring that companies adhere to high quality standards of financial disclosure. Material information about corporate events and actions must be disclosed to the public on an ongoing basis and made available as soon as is feasible. The Knowledge Bourse will require issuers to have a high-quality financial reporting infrastructure and prepare their annual accounts in accordance with high quality standards for accounting such as the International Accounting Standards Committee (IASC) and the International Organization for Securities Commissions (IOSCO). The Knowledge Bourse will require issuers to use auditing procedures based on standards of a high and internationally acceptable quality and that there is a mechanism in place to enforce compliance with accounting and auditing standards. Issuers must keep investors informed on an ongoing basis, largely through periodic financial statements, but also by announcing events and actions that have a material effect on corporate value. In this way, investors and intermediaries are able to assess factors that contribute to the price discovery process and make informed decisions as to whether they should deal.

Disclosure (to investors) includes: Financial and commercial results, company objectives, major share ownership and voting rights, members of the board, key executives and their remuneration, material foreseeable risk factors in the company set in the context of its industry, material issues regarding employees and other stakeholders, governance structures and policies, and implementations thereof. 
Comparability and reliability of financial information are critical to informed decision-making. The disclosure of such financial information includes:

- Information needed for the 'due diligence process' applied to listed companies

- Procedures on how the public and regulatory bodies can obtain disclosure from issuers

- Process needed for information to be made available to the public by issuers

- Issuer's responsibility for compliance with the standards of disclosure

- A statement of continuing obligations that provides a framework for issuers to fulfill their duty to the investing public by keeping the market fully informed at all times

- Rules on how issuers are bound to observe continuing disclosure obligation

In terms of the Sources of Funds for the Knowledge Bourse, the following would be apply:

- Fees must not be so great that they discourage issuance and trading of stocks;

- Registration fees for issuers

- Periodic registration fees for brokers and dealers

- User fee for brokers and dealers when they use the market

- Listing fee for companies listed on the market

- Periodic 'franchise tax' on corporations and other businesses

- Penalties imposed on those who violate the rules. Penalties should be applied fairly

Considering the Business Legal Form, there are different legal organizational models that have most commonly been adopted by exchanges:

- Nonprofit model

- For-profit model

- Consumer cooperative model
- Government-managed model

The implications of an exchange adopting any of the above legal forms will depend on the applicable jurisdiction.

A Nonprofit model for the Knowledge Bourse is recommended for the following reasons:

- It gives the bourses more flexibility in making decisions

- It minimizes the combined cost of ownership and control for all stakeholders dealing with the Bourse

- It is much simpler than other models

- Decisions will be based on profit and loss in a framework governed by legislation and supervision to ensure there will not be conflict of interest

- Eliminating the state's control would definitely reflect positively on the market, but it must be accompanied with enhancing both the level of disclosure and level of transparency

Accordingly, the Business Legal Form of the Knowledge Bourse should be a Commercial Mutual Nonprofit Firm:

- Commercial: Refers to the fact that a nonprofit income derives primarily for offering financial intermediaries a marketplace on which to deal for a fee

- Mutual: Refers to the fact that the agents who are the prime source of a nonprofit's income also control the organization, which means that the financial intermediaries who trade on the Bourse also control it

- Nonprofit: Refers to the fact that the firm is restricted from distributing any profit or surplus that it earns outside the firm and it is allowed to pay only reasonable compensation to its management

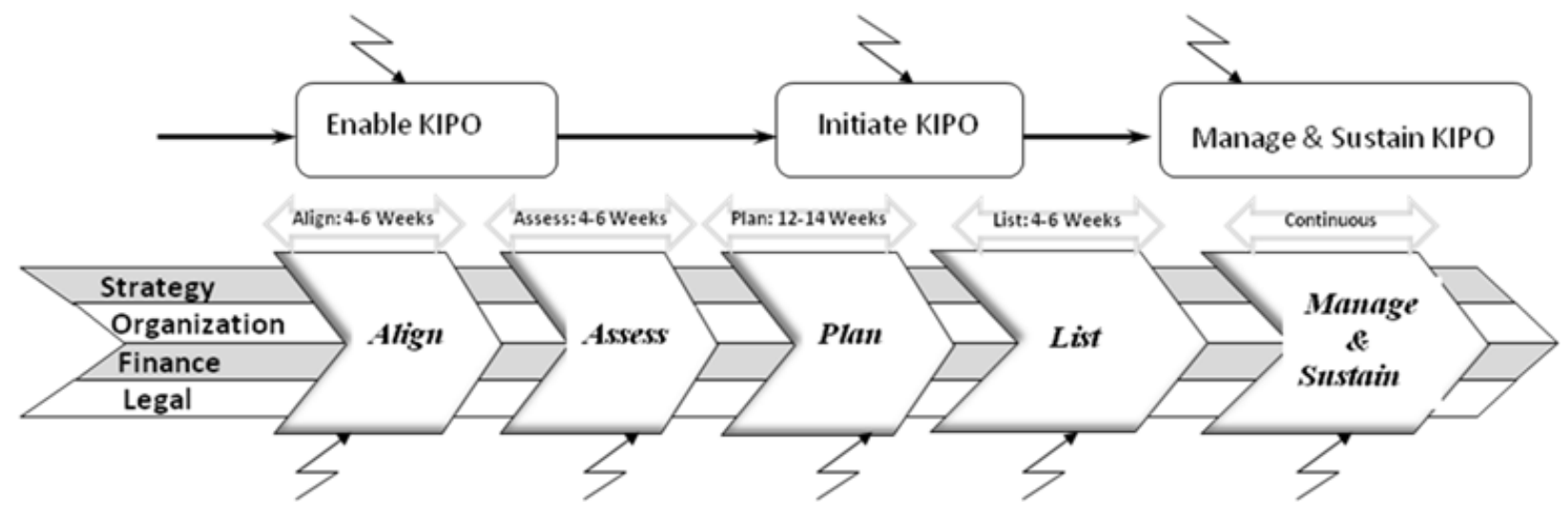

Fig. 6. Knowledge Stock Initial Public Offering (KIPO) process 
As a Commercial Mutual Nonprofit Firm, the Bourse will be controlled by and run for the consumers of the firm. It cannot distribute any profits and it cannot operate if its cumulative losses exceed its cumulative gains. The vision of the objective function of the firm is to maximize consumer surplus subject to breaking even.

Of special importance are the procedures under which KIPOs would be created. Figure 6 shows the process of knowledge initial public offering (KIPO) issuance and maintenance. The KIPO process shown in Fig. 6 comprises three major actions: enable KIPO, initiate KIPO and manage and sustain KIPO. More specifically, the process comprises several actions: First, alignment takes from 4 to 6 weeks and involves:

- Creation of a winning team that comprises 3 core teams

- Internal Team: company's executive management team (CEO, CFO and/or $\mathrm{COO})$ that will represent the company to the financial community

- Board of Directors to oversea all operations of corporate management

- External Advisory Team, including legal and underwriters advisors

- Development of the knowledge based-company's business strategy: Addressing the principle questions:

- Where are we today? Where are we going with our business? How will we get there?

- Stakeholder strategy: The development of a coherent and credible story why the company is raising funds and what the company will do with the proceeds to communicate with underwriters, investors and employees.

Assess comprises:

- Assessment of current versus future state of the knowledge-based organization in terms of appropriateness for a public company

- Identification of gaps between this current and future state

- Assessment of barriers to KIPO process \& develop risk mitigation approach

- Definition of metrics for future vision

- Identification of benefits and costs of KIPO process

- Development of KIPO value proposition/business case

Plan comprises:
- Executive Summary: A brief summary that explains company's story and why a potential investor should make an investment in the business

- Company Summary: An overview of the business and the key competencies that differentiate the company from its competitors

- Service \& Products: A description of your products/services from customer's perspective, highlighting competitive advantages, product lifecycle, R\&D that yielded a competitive edge

- Market Analysis: A description of your industry, target markets, competitors and outlook for the future

- Marketing and Sales Strategies: Analysis of strategies for business growth and achievement of sales targets

- Operating Techniques and Strategies: Overview of production and service delivery capabilities, current advantages and future opportunities for improvements describing how delivery of services/products to your customer compares to your competitors

- Management \& Ownership: An overview of key managers, plans for adding new members to the management team, current ownership and structure, and board of directors

- Financing Requirements: A summary of the company's current capital structure, short and long term financial needs, plan for using proceeds from new financing sources

- Financial History and Projections: Historical financial statements for the past 3-5 years and projections for the coming 3-5 years

- Identify the tasks to be completed based on: Company assessment, KIPO process elements and business plan

- Develop Work Breakdown Structure (WBS)

- Identify task owners, budgets and planned completion dates

- Develop a tax plan that covers: How the IPO will affect the owners/managers financial situation? What is the pre-KIPO tax and personal financial plan? How do owners/managers minimize income tax liability and how to protect assets? What are the legal techniques that allow stockholders to avoid or defer taxes when the company goes public?

- Develop a campaign plan to create a new company image

- Prepare effective and timely internal financial reporting systems, including skilled personnel and reliable systems, to provide required financial data

- Plan and implement a process of how the internal reporting systems roll up information and report it to the top management

- Prepare a system of internal controls

- Prepare a financial statement for the years the company has been in existence ( 1 to 3 years): 
- Audited balance sheets as of the end of each of the past 1-2 fiscal years

- Audited statements of income, cash flows and shareholders' equity for the past 2- 3 years

- Unaudited interim financial statements for the past 3-9 month

- Develop investment plan that considers questions such as: What is the plan of investing cash by selling stock in the public knowledge stock market? What is the best way to get the return needed with an affordable amount of risk? What is the investment diversification strategy? Does the compensation plan need to be reexamined? Should a stock option plan be implemented? Should additional options be granted under existing plans

- Plan for audit requirements

- Anticipate the needs of underwriters and coordinate with auditors to prepare for these requirements

- Timely disclosure and public relations

- Plan and implement internal forecasting and budgeting processes and systems to meet the needs and expectations of the underwriters

- Plan, collect and understand the performance expectations and demands of the market benchmarks

- Review last minute changes in capitalization

List comprises:

- Draft registration statement

- Prepare presentations for future road shows to tell the story to the people who will help sell the company's securities

- All Hands Meeting \#1: Hold the first "all hands" meeting to be attended by all members of the working group

- After the meeting, the company counsel prepares a very detailed timetable, assign responsibilities and due dates for the preparation of various parts of the registration statement and completion of numerous tasks

- Draft nonbinding letter of intent between the company and the lead underwriter to confirm the nature of underwriting, underwriter's compensation, number of shares or the amount of securities expected to be issued and the anticipated price

- All Hands Meeting \#2: Hold the second working group meeting to review the initial draft of the registration statement after the attorneys have consolidated all the inputs of different sections received. The members review the draft and agree on revisions

- All Hands Meting \#3: The third working group meeting will be held to review a printer's proof of the registration statement and execute signature pages
- Filing: File the initial registration statement with the appropriate authorities

- Road Show: Company Executives and managing underwriters start the road show to meet with perspective investors to discuss the company and the offering

- All Hands Meeting \#4: All members meet to address and review authorities' comments and approve amendments to the registration statement and finalize pricing

- Filing: File the final registration statement with the appropriate authorities

- Closing: Authority declares that the registration statement is effective and issues the proceeds of the offering to the underwriters and the company. At closing, documents are executed and exchanged

- Listing: List the company on the Knowledge Bourse or take securities over the counter

Manage and Sustain comprises:

- Price stabilization and overallotments. During the initial trading period, the underwriter may engage in certain stabilizing transactions to guard against sudden downward pressure on stock price caused by speculators

- Periodic reporting: Prepare required quarterly and annual financial reports

- Balancing short term profits and long term growth

- Completing initiatives on time and on budget

- Meeting or exceeding market expectations. Under promise and over deliver, maintain focus by continuously managing business diligently, mange the company and produce results

- Managing internal investors. Ensure that internal investors are thoroughly informed about insider trading rules and the policies for handling these rules and blackout periods

\section{Conclusion}

\section{The Promise of a Knowledge Bourse}

A Knowledge Bourse would provide avenues for the participation of a large base of knowledge workers and experts on the local, regional and international levels in the process of building a knowledge society and thus facilitating the transition to a knowledge economy in a given nation. The process of trading in knowledge stocks and knowledge futures has already been conceived and developed by pioneers who have been working for over a decade on R\&D in different facets of knowledge investment. A road map was designed and drawn to implement a Knowledge Bourse both as part of the Exchange market and as an independent entity specialized in knowledge trading (Tayeb and Al-Filali, 2011 ; 2012). The invention provides for systems and 
methods to establish a Bourse specialized in trading in various forms of knowledge encompassing inventions, intellectual properties and any type of explicit knowledge that have value in the marketplace. The creation of a Knowledge Bourse will provide a market for trading in knowledge stocks and commodities of different types. Both in these specific financial knowledge initiatives and general knowledge initiatives, nations have the opportunity to embark on an ambitious development project to promote a knowledge economy. But nations must hasten (ahead of others) to achieve a greater stature in the market for knowledge, as success in this venture (like all economic ventures) will fall disproportionally on first-movers. An enlightened and perspicacious nation would be a prime candidate to take advantage of such an opportunity and as a first-mover would be in a position to ride the strong currents of globalization to a more prosperous future.

For implementation of the Knowledge Bourse in Saudi Arabia whether as part of the Saudi Exchange "Tadawul" or as an independent entity specialized in knowledge trading, the trading rules and financial instruments have to be strictly tailored according to the Sharia. This requires inventiveness in the design of new instruments different from commonly known financial products. This is in addition to the use of existing instruments that are consistent with the Islamic traditions, especially those investments that are cited in the Charter of the Islamic Banking System and other Islamic Investment models. A Saudi Knowledge Bourse is likely to lead to a globally acceptable Islamic Knowledge Bourse.

Generally, further work is needed to develop special financial instruments as well as novel trade tools for an independent Knowledge Bourse, compatible with an economic environment driven by innovation and inventiveness.

\section{Acknowledgement}

The authors would like to thank the anonymous reviewers of this manuscript, as well as a list of other individuals to long to mention here. The authors would also like to acknowledge the editors' efforts in bringing this manuscript to publication. Finally the authors owe a special thanks to Abdo Husseiny for his organizational and logistical contributions in bringing this research project to fruition.

\section{Funding Information}

The authors have no funding to report.

\section{Author's Contributions}

All three authors designed the research plan, organized the study, and contributed to the writing of the manuscript.

\section{Ethics}

This article is an original piece of research. The corresponding author confirms that all of the other authors have read and approved the manuscript and with no ethical issues involved.

\section{References}

Acemoglu, D. and J.A. Robinson, 2012. Why Nations Fail: The Origins of Power, Prosperity and Poverty. 1st Edn., Profile Books, London, ISBN-10: 1847654614, pp: 320.

Allen, F. and D. Gale, 1994. Financial Innovation and Risk Sharing. 1st Edn., MIT Press, Cambridge, ISBN-10: 0262011417, pp: 379.

Back from the Dead, 2014. Economist, 11: 59-60.

Bookstaber, R., 2007. A Demon of Our Own Design: Markets, Hedge Funds the Perils of Financial Innovation. 1st Edn., Wiley, Hoboken, N.J., ISBN-10: 0471227277, pp: 276.

Dolgin, A., 2012. Manifesto of the New Economy. 1st Edn., Springer-Verlag Berlin Heidelberg, ISBN-10: 978-3-642-21276-5, pp: 145.

Drucker, P.F., 1966. The Effective Executive. 1st Edn., Harper and Row, New York.

Drucker, P.F., 1969. The Age of Discontinuity: Guidelines to Our Changing Society. 1st Edn., Harper and Row, New York, pp: 394.

Elul, R., 1995. Welfare effects of financial innovation in incomplete markets economies with several consumption goods. J. Econ. Theory, 65: 43-78. DOI: $10.1006 /$ jeth.1995.1002

Goetzmann, W.N. and K.G. Rouwenhorst, 2005. The Origins of Value: The Financial Innovations that Created Modern Capital Markets. 1st Edn., Oxford University Press, Oxford, ISBN-10: 0195175719, pp: 404.

Graham, B., 2004. Security Analysis. 1st Edn., McGraw Hill Book Co., New York.

Mitrany, D., 1966. A Working Peace System. Quadrangle Books, Chicago, pp: 221.

North, D.C. and R.P. Thomas, 1973. The Rise of the Western World: A New Economic History. Cambridge University Press, Cambridge, U.K., ISBN-10: 0521290996, pp: 170.

Powell, W.W. and K. Snellman, 2004. The knowledge economy. Ann. Rev. Sociology, 30: 199-220. DOI: 10.1146/annurev.soc.29.010202.100037

Shiller, R.J., 2012. Finance and the Good Society. 1st Edn., Princeton University Press, Princeton, ISBN-10: 1400841585, pp: 304.

Shiller, R.J., 2013. Capitalism and financial innovation. Financ. Anal. J., 1: 21-25.

DOI: $10.2469 /$ faj.v69.n1.4 
Tayeb, O.S. and I.Y. Al-Filali, 2011. Knowledge bourse. US Patent Application No. 61/527,452.

Tayeb, O.S. and I.Y. Al-Filali, 2012. Knowledge as a commodity: A trading primer. Center for Strategic Studies, King Abdulaziz University, Jeddah, Saudi Arabia.

Tufano, P., 2003. Financial Innovation. In: Handbook of the Economics of Finance: Corporate Finance, Constantinides, G.M., M. Harris and R.M. Stulz (Eds.), Elsevier, Amsterdam,

ISBN-10: 0080495079, pp: 307-355.
World Bank, 2007. Building Knowledge Economies: Advanced Strategies for Development: WBI Development Studies. 1st Edn., World Bank Publications, Washington, D.C., ISBN-10: 082136958X, pp: 191. 